\title{
The Impact of Protestant Spirituality in Catherinian Russia: The Works of St. Tikhon of Zadonsk
}

\author{
Andrey V. Ivanov \\ The University of Wisconsin-Platteville \\ ivanovan@uwplatt.edu
}

\begin{abstract}
:
This article examines the impact of Protestant-particularly Pietist-spirituality on the works of St. Tikhon (1724-1783), the bishop of Voronezh and Zadonsk. Hailed as the paragon of Russia's authentic spirituality (by nineteenth-century philosophers and church officials), St. Tikhon wrote deeply devotional literature for lay and clerical audiences alike. Although his writings arguably catalyzed the monastic revival in late eighteenth-century Russian Orthodoxy, they were deeply influenced by Protestant authors. Tikhon's works borrowed heavily from the writings of Johann Arndt (1555-1621), an inspirer of German Pietism, in theology, style and content, and to a much lesser extent from the writings of the Anglican bishop Joseph Hall (1574-1656). Even though this article is not the first to mention such influence on St. Tikhon of Zadonsk, it documents-to the fullest extent available in the literature-the scope and depth of textual, thematic, stylistic and theological appropriation of Johann Arndt in Catherinian Russia, in the particular case of the bishop of Voronezh.
\end{abstract}

Keywords:

Orthodox Church, Pietism, Anglicanism, devotion, monasticism, St. Tikhon of Zadonsk, Johann Arndt, Joseph Hall.

St. Tikhon (Sokolov) of Zadonsk, the Bishop of Voronezh and the Don (1724-1783), was probably one of the favorite saints of Fyodor Dostoyevsky. Canonized in the year of emancipation in 1861, St. Tikhon was one of the nineteenth-century writer's spiritual role models, or "historical ideals," alongside the traditional symbols of Russian piety, such as saints Sergii of Radonezh and Theodosius of the Caves. ${ }^{1}$ In fact, Dostoyevsky based his characters of Father Zosima in the Brothers Karamazov and Tikhon the Elder in the Devils on the saint, depicting them as the guardians of organic Russian Orthodoxy against the Westernizing and nihilistic tendencies of his age. ${ }^{2}$

Dostoyevsky was not alone in elevating this eighteenth-century saint to the status of a pillar of authentic peasant Orthodox piety, unadulterated by the pernicious influences of the West. His views reflected the broad intellectual fascination with St. Tikhon in post-emancipation Russia. For Moscow theologian Nikolai Sergievskii (1827-1892), he was the "champion" (podvizhnik) of Russian spirituality during a "time" that was "hostile towards the sons of the Orthodox church," that is, the eighteenth century, with all its Westernizing trends. ${ }^{3}$ 
Nicholas Berdiaev, the Russian philosopher, considered Tikhon to be a rare defender of the "freedom of thought and conscience" during the age of state repression of church spirituality. ${ }^{4}$ For Georgii Fedotov, another Russian religious philosopher, Tikhon represented the continuation of the "holy hierarchs" tradition of Russian Christianity, together with its medieval ascetics like Pakhomii Logofet and St. Stefan of Perm. ${ }^{5}$

This idealization of the saint, however, was partly fictional, partly reflective of the intellectuals' wishful thinking, and partly influenced by the fact that Russian Orthodox monastic communities held Tikhon's devotional writings in high esteem. It was also partly true: he was, after all, a peasant who had climbed the ladder of church hierarchy to become a bishop in Catherinian Russia, albeit he was not the only one. Synodal Bishop Innokentii Nechaev, for example, was a former serf of the Naryshkin estate, while Archbishop Simon Lagov was born in a monastery serf family. ${ }^{6}$

As my earlier work on St. Tikhon of Zadonsk illustrated, the life of this bishop mirrored the trajectory of many prolific hierarchs of the eighteenth century. Far from being a rebel against Petrine and Catherinian "synodal Orthodoxy," Tikhon Sokolov imbibed Protestant-inspired theological learning as a young seminarian, taught from Protestant textbooks as a seminary teacher, and embraced the Petersburg-mandated standards of popular piety and social discipline to change the rhythms of parish life in the somewhat unruly Don Cossack region of Voronezh. ${ }^{7}$

While my previous article focused on the life and accomplishments of the bishop, this article will offer an in-depth exploration of the Protestant theological influences in his devotional writings. Far from being representative of the "historical ideal" of Russian "organic spirituality" (that nineteenth-century thinkers attributed to him), Tikhon's writings reflected the very obvious imprint of Pietist devotional literature. The writer that influenced the saint the most was the seventeenth-century German Lutheran bishop Johann Arndt (1555-1621), especially his four-volume opus Wahres Christentum (True Christianity), which was first published in 1610. Tikhon's devotional writings were influenced primarily but not exclusively by Arndt. Anglican observed meditations, popularized in the writings of the seventeenth-century Bishop of Exeter and Norwich, Joseph Hall (1574-1656) constituted another, albeit marginal, source of influence on St. Tikhon of Zadonsk.

Why was Tikhon attracted to Arndt and Halle Pietism in particular? Although it is impossible to fully discern the true motivations of the saint's devotional preferences, it is entirely plausible that Tikhon's attraction to Protestant spirituality stemmed from the context in which he lived and from the fact that he (as well as other bishops of the time) may have found such devotional writings to be personally edifying.

The context of Tikhon's intellectual milieu in the eighteenth-century Orthodox Church has already been vividly described in my previous article. Russian seminaries used Lutheran theological writings widely at the time. Pietists, however, had developed particularly strong ties to Russian Orthodox hierarchs in 
the first half of the eighteenth century. It is worth mentioning that by the early eighteenth century, Pietism was far from a marginal movement within Lutheranism, but rather an established trend that influenced universities and parishes alike. It was essentially "the forerunner, the road breaker and the primer of the Enlightenment" throughout German Protestant lands. ${ }^{8}$ The author of Russian church reforms, Archbishop Feofan Prokopovich, for example, befriended a number of Pietist scholars (such as A. H. Francke, J. F. Buddeus and J.T. Jablonski), with whom he corresponded and who defended him in his various theological polemics with the opponents of his church reform. ${ }^{9}$ In addition to Prokopovich, other hierarchs including Kievan archbishop Rafail Zaborovskii and the Archbishop of Pskov (and the future catechist of Catherine the Great), Simon Todorskii, maintained strong contacts with Halle - a fact very well documented by Eduard Winter. ${ }^{10}$ With financial help from Prokopovich and Empress Anna, for example, Todorskii translated and published the works of Johann Arndt, August Hermann Francke and J.-A. Freilinghausen into Russian. ${ }^{\text {II }}$ Among the works that Pietists especially revered was Johann Arndt's True Christianity. It appears to have been quite popular in Russia too. It went through four Russian translations between 1735 and 1800 , with editions published in $1735,1784,1790$, and $1800 .{ }^{12}$

Tikhon of Zadonsk, as well as other bishops of Catherinian Russia, did not think of these writings as just another fashionable trend emanating from the Early Enlightenment German lands, but also as valuable parish literature, likely fit for the spiritual edification (if not "confessionalization") of their people. ${ }^{13}$ Simon Todorskii once observed that "many of those who care for the salvation of their souls read these [Arndt's] books with great diligence." ${ }^{\prime 14}$ St. Tikhon certainly seconded such recommendation. He himself underlined that a good Russian Orthodox believer should read the Bible, "study it always, in the morning and at night and read Arndt [emphasis is Tikhon's] but visit other books as a guest ( $a v$ prochii knigi kak $v$ gosti progulivat'sia). ${ }^{\prime 15}$ Aside from the Bible no other book seemed to hold more devotional value for the saint than the work of Arndt.

As this article will further demonstrate, Protestant spirituality profoundly influenced the theology, style and content of the most well-known devotional and meditative writings of St. Tikhon. His book, On True Christianity ( $O$ istinnom khristianstve), and the treatise The Spiritual Treasure (Dukhovnoe sokrovishche) borrowed greatly from Johann Arndt's opus On True Christianity, which he had access to in Todorskii's Church Slavonic version (of 1735) and, likely, a Latin one. Tikhon's other treatise, An Occasion and Spiritual Meditation Thereof [Sluchai i dukhovnoe ot nego razmyshlenie] manifests numerous parallels with Joseph Hall's Occasional Meditations, which Tikhon read in Latin editions as Meditatiunculae Subitaneae eque re nata subortae of $1635 .^{16}$

In the nineteenth century, the theological connection between Tikhon and Arndt was likely assumed, but never officially acknowledged. In fact, the Synodal editor of the 1889 edition of Tikhon's works warned against contemplating such a relationship, stating ex officio that the "two books do not have the least thing in common." ${ }^{\prime 7}$ Several twentieth-century church historians, including Georges 
Florovsky, Nadejda Gorodetzky and Pavel Khondzinskii, acknowledged the connection more boldly, yet produced no extensive textual research to substantiate this claim. ${ }^{18}$

Despite the efforts of the 1889 editors to eliminate any of the readers' doubts about the authenticity of Tikhon's Russian spirituality (unsullied by Western influence), the textual, stylistic and substantive connections between Johann Arndt and Joseph Hall on the one hand and Tikhon of Zadonsk on the other were significant. Although the works are quite different in volume-Arndt's work is longer than Tikhon's, and Joseph Hall's work is just a treatise-parallels between them go beyond simple resemblance. Textually, Tikhon did not only paraphrase from German and English theologians, but utilized inserted phrases, paragraphs, and examples. He also adopted the same scriptural quotations as Arndt, whenever a similar subject or topic was concerned, even where the rest of the text was a loose paraphrase. Tikhon also relied on these authors to imitate their devotional style of writing, which was characteristic during the unique period of European literary Baroque. ${ }^{19}$

The scope of direct textual and stylistic parallels between Tikhon and the abovementioned authors is too wide to cover in the confines of this brief study. Therefore, this article shall limit itself to several substantive categories that were of central theological importance to the worldviews of Tikhon and Arndt, as well as to Christianity in general. The first category that I will explore is the description of soteriology (theology of salvation) in the writings of the German bishop and the Russian saint. The second category will cover penance and regeneration, while the third will focus on the ways both authors described Christian virtues. Tikhon's observed and reflective spiritual meditations (as inspired by Joseph Hall's work) will constitute the final topic of this comparative study.

\section{Soteriology and Justification}

The theology of salvation occupies a significant place in the writings of Pietist authors and St. Tikhon of Zadonsk, and reflects the impact of Protestantism on Orthodox theology of the time. In Russia, the debate on salvific theology went back at least to the early eighteenth century. Thus, one of the major debates between the Protestant-leaning bishop Feofan Prokopovich and the Jesuiteducated Stefan Iavorskii focused on the soteriological nature of faith, and the nature of justification. While Iavorskii declared grace-enabled works to be salvific and viewed justification as a "means" towards salvation, Prokopovich held a more Protestant line. ${ }^{20}$ He understood justification in a purely legal sense-justificatio forensic - as acceptance of Christ's redemption (via substitution of punishment) and salvation as an accomplished fact accepted through faith. ${ }^{21}$ In contrast to Iavorskii, he also held a low anthropological view of total depravity and the corruption of human nature. ${ }^{22}$

Low anthropology is a prominent feature in the works of St. Tikhon and Johann Arndt alike. Both authors argued that humans were created in the perfect 
image of God, which the fall into sin corrupted and transformed. Both utilized the metaphor of a mirror to describe the original created state. The human soul, Tikhon wrote, was originally a reflection of God's personhood, "just as (iakozhe) the image (obraz) of someone looking into the mirror is similar to the one who looks into it." ${ }^{23}$ For Arndt, similarly, humankind originally reflects the image of God "just (iakozhebo) as the image (obraz) cannot appear in the mirror, unless it takes the semblance or reflection from the one, looking into the mirror."24 However, due to the fact that the "sinner turned his back to God" (Tikhon) and "turned away from Divine Being" (Arndt) humankind lost this reflection of the divine and became evil. ${ }^{25}$

Thus, for Tikhon, the condition of the human heart was "evil," to a degree that it "cannot change or soften by exhortation, threat, mercy, or harshness." Having no regard for divine law, "his sin-loving heart is like a vile temple, in which he brings sacrifices to his idol." ${ }^{26}$ Worst of all, this miserable condition caused humans to become diabolical children. "It is very catastrophic and horrible to be the son of the devil," argued Tikhon. "But the sin, evil and diabolical seed, leads man to this horrible catastrophe (bedstvie)." ${ }^{27}$ The seed of Satan causes the sinner to reflect his wicked progenitor: "he bears an image (izobrazhaet) of this prince of darkness by his mores just like the son resembles the father and by this deed manifests that he descends from that vile father of his." 28

Tikhon's anthropology paralleled the cardiocentric views of Johann Arndt. The German theologian argued that Adam's fall "first occurred in his heart," 29 making it "adamical, vile and beastly." ${ }^{30}$ Furthermore, humans became idolators, and "children of the devil [...] for if you enter the temple of your heart, you will see plenty of vile animals, images and idols. You bring sacrifices to them and serve them. ${ }^{31}$ He argued that "the seed of the serpent" implanted in man, molded the

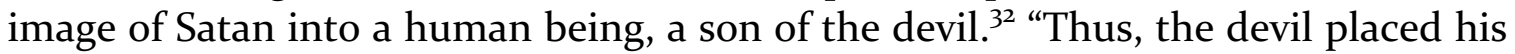
image (izobrazil) in man and planted his serpentine seed through poisonous, devious, and tempting words." 33 Thus, humans imitate their fathers, "bearing the image of the devil in man, being from this seed the devil's children." 34

For Tikhon, acknowledgement of one's depravity (okaianstvo) and acceptance of substitutional, legal justification constituted the solution to this pitiful condition of the human soul. First of all, the sinner must approach God for treatment of his sinfulness, who is compared to a "doctor treating sickness." 35 Whoever seeks this treatment, needs to cast away "his false righteousness" (mnimoiu svoeiu pravdoiu) and acknowledge "his incapacity [to become righteous] and his depravity" (svoeia nemoshchi i okaianstva). "For whoever does not see his inability and does not acknowledge it," he argued, "seeks no doctor, for the truly sick are those who are sick in heart. Not the healthy have a need of the physician but the sick." ${ }^{6}$

The argument and imagery employed by Tikhon closely parallel the text of Johann Arndt in his chapters on faith and justification. In his first part of the fourvolume work, the German theologian equally acknowledged the need for human beings to receive justification to overcome the condition of sin, comparing it to a 
sickness that is in need of a "doctor and medicine." ${ }^{37}$ In order to receive this cure, humans must set aside their "righteousness from works" and "come to the knowledge of our powerlessness (nemoshchi)." "The healthy need not the physician but the sick only," he continues, "lest they acknowledge their spiritual incapacity." In addition to the acknowledgement, one needed to exhibit "sorrow in the heart for his sins," since it is one's "corrupted heart" that needs cure from sickness. ${ }^{38}$

The actual acceptance of justification comes through faith. "For one's justification before God is through faith only (tochiiu very)," wrote Arndt. ${ }^{39}$ It is through faith that one receives righteousness [pravda] as a gift, like "some newborn, small, child (otrocha) that stands naked before his Redeemer without clothes," and through faith receives "the clothes of God's mercy." ${ }^{40}$ Furthermore, this faith "places Christ in you," and with God dwelling inside one becomes "a beautiful and new tree on which the fruits are love, patience, humility." ${ }^{41}$ The bearing of fruit is the natural indication of what Arndt called the "living faith," and such faith would never bring "dead fruit" or "an evil, poisonous" one. ${ }^{42}$

Likewise, for St. Tikhon, faith is central to this process: "for no one can become justified before God and be saved without Christ and outside Christ but only by faith (tokmo veroiu) in Christ." 43 Tikhon illustrated the reception of justification via an example of a child: one "resembles a small child (otrok) that stands naked before his mother and asks for clothing" and in return receives "such clothes, the clothes of justification (opravdaniia) [...] which are the righteousness (pravda) of Christ he receives by faith." ${ }^{44}$ Christ therefore covered the believer by his righteousness or justification (the Russian term pravda could mean both) without any merit whatsoever, as child-like trust was the only condition for being justified "by faith in Christ." 45

Christ, Tikhon wrote, not only covered a Christian with righteousness, but also dwelt in him. ${ }^{46}$ Through faith, he wrote, "the grace of Christ" took away one's sins and "settles in the heart," thus becoming a "living faith." ${ }^{47}$ The primary indication of such "living faith" lay in the presence of good works: the "faithful man," he wrote "resembles a tree, but without the fruits the tree is useless and dead." ${ }^{48}$

\section{Regeneration and Repentance}

For both Arndt and Tikhon, such child-like acceptance of what Martin Luther once termed "alien righteousness" made of a true Christian a "new creation" or a "new birth." 49 The idea of regeneration provided a theological solution to the problem of total depravity. It also constituted a common theological denominator linking the writings of these two authors with European Pietism in general, and Philip Jakob Spener (1635-1705) in particular. Spener's theology of regeneration centered on the notion of restoring imago dei in humankind through a new birth (Wiedergeburt) alongside the natural one and the spiritual formation of a new man (Neuer Mensch) alongside the old, adamic self. As a good Lutheran, Spener argued 
that this "new birth" occurred at baptism, which in turn, sealed a Christian's membership in the "covenant of faith." ${ }^{\circ 0}$ Yet, the fact of infant baptism alone was no "comfort" for salvation to the adults, Spener argued. Instead, believers were to manifest their regeneration regularly through the practice of "sincere repentance." "If your Baptism is to benefit you," he wrote, "it [repentance] must remain in constant use throughout your life." ${ }^{\prime 1}$ As a result, continual penance and selfimprovement stood out as major hallmarks of Pietist innovation in Lutheran theology. ${ }^{2}$

The idea of regeneration is a recurring central theme in the works of both Tikhon of Zadonsk and Johann Arndt. St. Tikhon identified three main elements through which one is able to be born again: " 1 ) by faith in Christ who said that "whosoever believes that Jesus is Christ is born of God" [1 John 5,1]; 2) by the Holy Spirit, "whoever is not born of the water and Spirit cannot enter the kingdom of God" [1 John 3,5]; and 3) by holy baptism, as Christ himself teaches, "as you go, teach unto all nations, baptizing them in the name of the Father, Son and Holy Spirit" [Matthew 28, 19]."53 Tikhon's ideas are virtually identical to those of Arndt, who argued:

This new birth occurs first of all by the Holy Spirit, as the Lord says about those 'born of the Spirit' [John 1, 5]; secondly by faith as 'whoever believes that Jesus is the Christ, is born of God' [1 John 5, 1]; and thirdly, by the holy baptism, 'whoever is not born of water and of the Spirit, cannot enter into the kingdom of God' [1 John 3, 5].54

For Tikhon, the new spiritual birth did not necessarily abrogate the effects of birth by flesh. In fact, a Christian lives with a dual personality - "for in every newly-born Christian there are two generations, as well as two men (cheloveka) with their own qualities, that are old and new." 55 This duality created a conflict between the two states of a Christian's nature. For example, "by fleshly [birth] one is prone to drunkenness, intemperance (nevozderzhaniiu), uncleanness (nechistote)," while "the spiritual [birth] calls one to temperance, abstinence and chastity." It also affected one's thinking as well as judgment: "Fleshly birth inclines the Christian towards fleshly wisdom or judgment (mudrovaniiu), while the spiritual-towards spiritual wisdom," he wrote. ${ }^{56} \mathrm{~A}$ new birth and its manifestations are ultimately the mark of a "true Christian," whom Tikhon contrasts against the archetype of a "false Christian," who shows no signs of new birth, despite one's baptism and profession of faith. ${ }^{57}$

Johann Arndt's text also shows a strong preoccupation with conflict. "There is therefore a two-fold birth; and consequently, two men, as it were in one and the same person." ${ }^{8}$ From one nature, humans inherited a "shameless, unclean (nechistago) and intemperate (nevozderzshatelnago) spirit," while the other bestows upon him "a spirit of purity and good temperance."59 "From Adam one received the spirit of earthly wisdom (zemnaia mudrstvuiushchago), while from Christ he ought to receive by faith the spirit of heavenly and godly wisdom." 
Living according to the new birth is clearly a sign of the "real Christian" as opposed to the "hypocritical false Christian," who simply professes his faith (the specious name of faith) but shows no signs of new birth. ${ }^{61}$

Yet such regeneration did not make one immune to sinful behavior. Nor was one immune from sinning and backsliding. Johann Arndt and Tikhon of Zadonsk were quite aware of the theological dilemma presented by the fact that a new-born, "true Christian" had to live in the un-regenerated flesh and surrounded by the degenerate world. To solve this problem Johann Arndt and, consequently, Tikhon of Zadonsk, introduced the terms "repentance" (pokaianie) and "conversion" (obrashchenie) as hallmark experiences of every true Christian. Conversion with penance was a necessary antidote to sin.

Both authors relied on the metaphor of bodily motion to describe the process of conversion. For Johann Arndt, the human condition was a motion away from God or a "backsliding" from him. To overcome it, one needed to heed Prophet Jeremiah's advice to "turn unto God with your heart (serdtsem obretitisia)" away from backsliding. ${ }^{62}$ Repentance par excellence for him meant "turning." Similarly, Tikhon's text also employs a passage from Jeremiah showing that whoever disobeys God "changes his good will (proizvolenie) and chooses evil instead of good, commits sin instead of virtue - he turns his face away from God and turns his back (khrebet) to Him." ${ }^{64}$

Both Tikhon and Arndt elaborate on the concept of motion through virtually identical expositions of the biblical parable of the prodigal son. In Tikhon's account, the sinner's prodigal "distance from God" is reinforced with the son's poverty (having wasted the inheritance), "living in infidelity," search for satisfaction according to the lost image of God, and spiritual hunger. ${ }^{65}$ At the urging of the Holy Spirit, the son, according to Tikhon, begins to contemplate about his present condition and "by the grace of God he comes to a realization of his error and depravity (okaianstva)." ${ }^{66}$ Furthermore "he sees the shortcomings and vices in his conscience, and attempts to purge them through prayer and contrition of heart" as he "runs back to the Father's house. ${ }^{167}$ Likewise, for Arndt the son comes to a similar self-realization: "as he comes to his senses, [the son] begins to contemplate about his depravity (okaianstvo) as a child of God." ${ }^{\prime \prime 8} \mathrm{He}$ then shows "contrition of spirit," as he contemplates "his origin, from whence he came, and mindful of his Father regrets his sin, realizes his unworthiness" and returns to his parent's estate. The reunion of the Father with a prodigal son is followed by both author's exclamation about God's merciful look. "Oh, the merciful eyes of the Father," wrote Arndt, "how caringly they look upon a profligate son!"69 "When God, the heavenly Father beholds"-exclaimed Tikhon"o how kindly he looks upon him! How dear can be his holy and merciful eyes!"70

Although the parable of the prodigal son provided a good model of repentance for both Tikhon and Arndt, it did not address the fundamental problem of divine and human agencies in the process of conversion. How does the sinner come to this realization of the need to repent? What actions should impel the son to return to his Father's estate? In order to explicate repentance 
theologically, the authors needed to identify the motives that would drive the sinner to despair and repentance. They also sought to explicate the role of divine and human actions in the process of conversion. To solve this problem, Johann Arndt offered seven "chief reasons (viny) that would impel (podvignuli) one to repentance," while Tikhon wrote about the virtually identical eight "causes that should induce the sinner towards repentance." ${ }^{11}$ The first three of these motivations strongly emphasize the role of divine agency, as well as past and present acts of God that should prompt the sinner to repent, while the others highlight future events that should motivate repentance. In their content and purpose, the passages by Tikhon follow closely the text of Arndt. ${ }^{72}$

Thus, the first motivation for repentance is "God's desire for salvation," or the "mercy of God," who desires human salvation and acts mercifully. "It is not proper for us to neglect the mercy of God's fatherly heart," wrote Arndt. This sentiment is paralleled by Tikhon's conclusion that "it is not proper for us to neglect this merciful God's desire."73 The second motivation involves the passion of God's Son, Jesus Christ, on behalf of the sinners. Both Arndt and Tikhon urge the reader to "recall" (pomiani) Christ's suffering and the shedding of blood that made redemption (iskuplenie) possible. ${ }^{74}$ The third incentive that should drive a sinner to repentance is God's present "admonition" (preshchenie) and threat of temporal punishment through destruction or pestilence. Here, both Tikhon and Arndt point to the past experience of Ninevites who repented and thus avoided such penalty for disobedience. ${ }^{75}$

The remaining paragraphs underline the importance of future events to motivating repentance. One of such incentives is death, which according to Arndt and Tikhon remains "unknown" to any human being. "God promised you his grace, but he did not promise you tomorrow," wrote Arndt. This finds a close parallel in Tikhon's words: "God promises to accept us repenting and give us absolution of sins, but he does not promise tomorrow." ${ }^{6}$ The "Last Judgment" (Arndt) or the "Doomsday Judgment of Christ" (Tikhon) forms another future event that induces penance. Here the "now" (nyne) of merciful God is juxtaposed against the "there/then" (tamo/togda) of the judging and wrathful God of judgment day. ${ }^{77} \mathrm{~A}$ similar notion is emphasized in the sixth motivation - the torments of hell - where God's mercy will "cease to be" (prestanet). Both authors conclude their list of incentives with a prospect of eternal bliss: only a fool would forfeit the eternal joy of the next life for the temporal one of this world. ${ }^{78}$

Overall, the believer would need repentance in order to carry out successfully what both authors highlighted to be "the struggle of flesh with the spirit (bran' ploti i dukkha)." ${ }^{\prime 79}$ A life of repentance, the renunciation of self, the "taking up of the cross," and the bearing of the "fruits" was thus an ultimate hallmark of a pious and true Christian. ${ }^{80}$

\section{Devotion and Christian Virtues}


Acceptance of the Pietist solution to the Protestant works-faith dilemma raised the question of the application of the concept of regeneration to everyday Christian life. Whereas the traditional Roman Catholic (and seventeenth-century Russian) notions of salvific merits relegated the most austere forms of spirituality to the ecclesiastical realms, Pietists and Puritans consigned them to the spheres of the private and mundane in often quite maximalist terms. Fervent prayer, the exercise of the highest virtues or inner enlightenment, was not solely a privilege of the monks, but of all true believers. In fact, for some, it was the marking point that separated true believers from the untrue ones. ${ }^{81}$

A true Christian for Arndt and Tikhon was one who exhibited all of the highest Christian virtues by practicing the rejection of the world on the one hand and the the love for God and for one's neighbor on the other. The term "contempt and rejection of the world" in Tikhon's rendering was primarily spiritual and did not imply the rejection of created matter as such, since "we cannot exist without them, and they are created for us so that we may use them." ${ }^{82}$ Neither was it isolation: "joining a monastery or desert community" was not the solution, since "many who live in the monasteries do not reject the world." ${ }^{83}$ These thoughts show parallels to Arndt, who expressed similar skepticism about monastic isolation, and for whom the "creatures" (or created things of the world) existed "for man's sake," and thus were perfectly suited for man's use. ${ }^{84}$ The only true way to reject the world was self-denial, described by Tikhon as the "crucifying of our flesh with its passions and lusts," and by Arndt as the "mortification of the flesh." ${ }^{85}$ The Christian experienced no belonging in the present world, being a "stranger and pilgrim" in it - a theme that occurs frequently in the both authors' thought. ${ }^{86}$ With the rejection of the love of the world, one embraced "true love," a notion that Tikhon and Johann Arndt divided into three relational categories: love of God, love of neighbor, and love of one's enemies.

Loving God was not only "natural" to a true Christian, but also enjoyable: the two writers underlined the "sweetness" of this love and the motivation it provided in sacrificing not only "fleshly desires" but also one's very life. ${ }^{87}$ To outline the nature of true Christian love towards God, both Arndt and Tikhon pointed to the "marks" or "signs" by which such love should be recognized. The first indication of "evangelical love" for Arndt is "fulfilling his [God's] commandments" not out of any compulsion or presumption of merit, but "from a principle of love to Him." The German theologian based this notion on a passage from the Gospel of John (14:15): "if a man loves me, he will keep my commandments." ${ }^{88}$ St. Tikhon likewise highlighted his first sign of God's love as "fulfillment of commandments, not for the sake of fear but so as not to offend the loved one," and based this aspect upon the identical reference to John 14:15. ${ }^{89}$

Another mark of true love for both Arndt and Tikhon consists in "avoiding the love of the world" and preferring the love of God instead. ${ }^{90}$ For Johann Arndt God's "sweet love" is superior to any love found in the world. In fact, this very property of God's love-its "sweetness" (sladost')—induces a Christian to overcome the "bitter sufferings of the cross (goresti krestnyia)." ${ }^{11}$ That is why, he 
explains, "the holy martyrs bore their sufferings in patience and joy, being satiated with God's love." ${ }^{2}$ Tikhon, likewise, employs a sucrose allegory to describe the preference of "this sweet love" (sladkoi sei liubvi) to the love of the world. ${ }^{93}$ This supernatural quality of God's love also assisted believers in overcoming crucial suffering. "Thus the holy martyrs rendered themselves to death and suffering for the sweetest name of Jesus the Lord as if they attended the sweet spiritual banquet." 94

But the exercise and virtue of loving God also required the adoption of love for one's neighbor. The latter constituted an extension of the former and was opposed to the love of 'created things' in itself. ${ }^{95}$ The True Christianities reinforced the notion of neighborly love by a series of causes (prichiny). One motive for neighborly love rested on the idea of humanity's inherent common lineage (created from a single ancestor) as well as the stipulation that it is impossible to love God without love of neighbor. ${ }^{96}$ For Tikhon humankind was bound together, "subjugated by one set of laws, and by them, connected by a bond (soiuzom) into one society." 97 Therefore, loving each other was crucial to the preservation of the human race: "the unity of society and the bond of its components need to be preserved by the bond of love without which it is destined for downfall." 98 This idea paralleled Arndt's assertion that "love is the first law of nature by which all the good proceeds to humankind and without which humankind will perish." ${ }^{99}$ Love acted through a "bond (soiuzom) of perfection" that tied all humans to each other, and even to the heathen, who was "convinced of it as of the law of nature."1oo While for non-believers who did not love God, loving each other was a natural means of self-preservation, Christian neighborly love was a manifestation of their affection for God. Loving God and each other united the believers as the "spiritual body of Christ" (Arndt) ${ }^{101}$ or as "the parts into unified body" (Tikhon). ${ }^{102}$

In Arndt's writings, Christian love provided "a foretaste (predvkushenie) of eternal life," where "God's elect will love each other, rejoice for each other in eternal joy and sweetness." ${ }^{103}$ For Tikhon, likewise, love was a "foretaste (predvkushenie) of eternal life, in which there will only be love for each other, only cheerfulness and joy for each other." ${ }^{104}$ But such love also transcended relationship categories, and included the love of all neighbors, including one's adversaries. Loving one's enemies was not a matter of choice but a duty of a true Christian: for both authors there were several crucial and convincing "causes" (prichiny) that impelled a believer to this practice. One cause was the very fact that Christ commanded such acts. ${ }^{105}$ Another was that such practice constituted a sign of being the child of God. "No one can be a child of God, unless he loves his enemies" wrote Arndt. ${ }^{106}$ "Whoever loves not only friends, but also the enemies," stated St. Tikhon, "shows that he is a son of God."107 The practice of loving one's enemies was illustrated by the example of Christ. Thus, Arndt argued that true believers should follow the model "of the Son of God himself, to forgive and love his enemies [...] who chose to pardon all these barbarous acts and to pray, 'Father forgive them!'”108 Similarly Tikhon's reading audience were to observe an example of Christ "who loved his enemies" and who "prayed about his crucifiers, "Father forgive them, for 
they know not what they do!"'109 Most importantly, however, love of one's enemies was the highest virtue a believer could achieve and the highest stage of Christian spiritual growth. "One cannot ascend to a higher virtue, cannot have a greater climb, [and stand on] a higher level (stepen') than loving enemies," wrote Arndt. ${ }^{10}$ This virtue was overall "a quality of the noble, godly soul." ${ }^{\prime \prime \prime}$ In the same manner, Tikhon classified "loving one's enemies" as "a high virtue."12 "Christians must ascend to the highest level (stepen') of love, that is love not only for those who love them, but those who hate them too," he stated."13

The only tangible enemy that Tikhon and Arndt argued one should wage war against was oneself, one's own depravity and $\sin ^{114}$ To make a vivid illustration, Arndt supported this point with references to Ovid and Solomon. "To score a victory over self is greater than all other victories," he wrote in an imprecise translation of Ovid's Latin original. ${ }^{115}$ As for Solomon, "He that rules his spirit is better than he that takes the city." Tikhon's dictum that "It is a more glorious and magnificent victory for a man who to conquer himself, than conquering cities and states."17

The love of God influenced not only the virtues of loving one's enemies and loving one's neighbor but also other spiritual traits of a Christian. For example, both joy and rejoicing in the True Christianities derive their moral mandate from the virtue of love. Arndt argued that, "there can be no joy without love, for joy is born (razhdaetsia) of love, and one has joy according to his love." ${ }^{\prime \prime 8}$ Rejoicing for a true believer "originates and grows out of the heartfelt love of God." ${ }^{\text {"19 }}$ Tikhon's chapter on joy closely parallels Arndt's chapter. "There can be no love without joy," the Russian bishop stated, "so wherever there is love, there is joy also. Whoever loves something, rejoices in it." ${ }^{120}$ Furthermore, he wrote, "the love of God gives birth (razhdaet) to true, heartfelt and inseparable joy." ${ }^{21}$ One's joy spiritually corresponds to one's sense of possessions, be they earthly or spiritual. "Whatever man loves, he rejoices therein," wrote Tikhon ${ }^{122}$ paralleling Arndt's distinction between "earthly" and "divine" possessions. ${ }^{123}$ Treasure, for Arndt, is "internal" "for we carry this treasure in our souls." 124 "This treasure," he argued, "increases (umnozhaetsia) and spreads itself infinitely" in the heart of the believer. ${ }^{125}$ In Tikhon's chapter also such possessions determined one's spiritual joy: "wherever his treasure, there his heart is," 126 adding later that, "this joy, in Christians, abundantly grows and increases (umnozhaetsia). ${ }^{{ }^{2127}}$ Finally, for both authors, the spiritual trait of Christian joy manifested a certain eschatological meaning. Arndt stated that "this is a foretaste (predvkushenie) of eternal life."128 "The faithful and God-loving soul," he continued, "feels some small sparkling and tastes some small drop of this eternal joy." 22 Likewise, for Tikhon, "this joy is a foretaste (predvkushenie) of eternal joy, [and] the true Christians now feel some particles of it." ${ }^{130}$

The virtues of love and the character of joy are not the only topics of Christian spirituality where Tikhon's borrowings from Arndt are readily apparent. The similarity in thought and argument, as well as style, is hardly limited to the subjects mentioned above. In his discussions on the further signs of true 
Christianity, Tikhon's themes continue to intersect with Arndt's in the chapters on humility ("On Humility," ${ }^{\prime 31}$ compare with Arndt's "On the Power of Humility"132), patience ("On Patience, Arndt's "On Patience"), ${ }^{133}$ prayer ("On Prayer," I, 299/ "Prayer is the Sign of True Christian," II, 105), and the narrow way ("On the Narrow Way" / "Narrow Way in Christ"), ${ }^{134}$ just to name a few.

\section{Spiritual Meditations}

Arndt's influence on Tikhon's works shows not only a level of inspiration that this German religious classic offered to a Russian bishop, but also a reflection of the eighteenth-century context in which he lived. This context encompassed a larger array of Protestant theological influences in Russian Orthodox Church, already discussed in the introduction. The saint's adoption of Arndt's soteriology, anthropology and the teaching on regeneration is an example of such influence. Protestant literature, however affected not only the doctrinal content of what the Orthodox Church hierarchs (including Tikhon) penned, but also the devotional, contemplative and meditative elements of their writing. A wide array of Protestant and non-Protestant meditations spread in Russia in the eighteenth century (including such authors as Jakob Boehme, Jakob Spener, Thomas à Kempis and Angelus Silesius). ${ }^{135}$ However, St. Tikhon appears to be among the pioneers of adopting it in his own writings, according to Nadejda Gorodetzky. This genre of Protestant, non-Ignatian rationalistic meditation developed in the seventeenth century and consisted of focused contemplation on particular natural or artificial objects or phenomena (animals, trees, human events, celestial objects, et al.), deriving larger allegorical or theological meaning from them. ${ }^{136}$

Tikhon's adoption of this genre of religious literature likely stemmed from his acquaintance with the work (or perhaps, works) of Joseph Hall (1574-1656, Bishop of Exeter and then Norwich), a prolific writer of devotional meditative literature. ${ }^{137}$ According to Frank Huntley, Hall's influence on English religious life has been substantial: his devotional works, for example, influenced the subsequent rise of seventeenth century Puritan meditations (as seen in the works of Richard Baxter), which (in contrast to Ignatian mysticism) emphasized the rational elements of devout observation. ${ }^{138}$

Both Gorodetsky and Florovsky maintained that Tikhon's Spiritual Treasure was influenced by the British bishop's Occasional Meditations (London: N. Butter, 1630; complete English edition, 1633). ${ }^{139}$ The work was widely available in Latin (the language in which Tikhon could actually read), as Meditatiunculae subitaneae in either the 1635 London edition or the 1672 version published in Koenigsberg. ${ }^{140}$ In carefully evaluating the two works, I found the semblance to be more of style than content; in fact, Tikhon's 1779 Spiritual Treasure shows a continuing influence of Arndt. ${ }^{141}$ At the same time, Tikhon's another treatise, entitled Sluchai i dukhovnoe ot togo razsuzhdenie (Occasion and Spiritual Meditation Thereof) had been overlooked by both Gorodetzky and Florovsky. This work appears as inserted in between the first and second sections (stat'i) of the first book of his True 
Christianity, interrupting the natural flow of that larger work $\cdot{ }^{142}$ While we do not know the year in which the saint composed Occasion and Spiritual Meditation, the nineteenth century editors of his volumes state that it emerged during his writing of True Christianity (which was based on the lectures he delivered in Tver seminary in 1750 ) $)^{143}$ It is this treatise (and not the Spiritual Treasure) that I argue shows far more parallels to the English bishop's Occasional Meditations than any other work of the saint. ${ }^{144}$

The similarities between Tikhon's treatise and the Occasional Meditations of Hall appear in style, imagery, textual content and even the volume of the text. The treatises are composed of meditations on various natural or artificial objects (such as fire, trees, clocks, fruits and so on) and they are both organized in the Roman numerical order: Tikhon's work has 146 object meditations, Hall's 140. The meditations usually begin by calling the reader to observe an object or material and to meditate upon it. The description of the object in both authors' works is followed by a brief homily highlighting the spiritual value of the sight observed. The mode of calling the reader to observe a given object is strikingly similar in St. Tikhon's and Hall's books. Thus, St. Tikhon calls upon his readers to observe each item with opening exhortations containing a word or a phrase such as "See (vidish')," "When you happen to see (sluchaetsia tebe videt' or ashe by ty uvidel),"145 "When you see or hear (vidish' ili slyshish'),"146 "don't you know (znaeshi li or znaesh)" as well as "When you look (smotrish')."147

This mode of summoning the reader to focus upon a meditative object is often similar in Hall's book. The English edition uses "see!" "Lo!," "see how..." or "Behold..." rendered in Latin as "ecce," as in "'See there are two snails (Ecce istic duos limaces)," as well as in the various forms of the verb videre (such as "vide modo," "vides" or "vidimus"). ${ }^{148}$ The author also uses "Hark (hear) how... (audi modo...)," "I9 "I know (nescio)",150 as well as "I look (intuero)."151

The ways in which both authors described the purposes of their works are also similar. Both treatises aimed at popularizing this distinct devotional practice. Thus, in his 1635 foreword, Proloquium ad Lectorem Joseph Hall states that the booklet [libellus] is written to "go into the crowd (prodire in vulgus)" and that it is not written "for more elegant embellishment, but for introducing natural simplicity (non ornatas elegantius, sed native simplicitate inductas)." This mode of meditation, the author argues, is best suited for the simple folk because they comprehend things better visually. "This is how indeed the human soul becomes more alert (agilis)," states Hall, "it comprehends (cogitet) nothing better than what it sees (videat), what is opened by the eye (oculus apertus)."152

In a very similar designation of purpose, Tikhon instructed that the meditations in his tract "are first of all (naipache) written for the simple people (radi prostogo naroda - emphasis by the author), who cannot comprehend the teachings on sacred matters." 153 For Tikhon, too, the best mode of learning is the visual one. "No instruction (uchenie) is comprehended (poniatnym delaetsia) and explained (iz'iasniaetsia) better than by the images (podobiia) of those things, 
which can be felt or which appear before our eyes (pred glazami nashimi obrashchaiutsia)." 154

Thus, the two texts commence by thrusting the reader into the motions of the sky above them. Joseph Hall's first meditation observes "the sight of heavens moving (conspecto caeli motu)," especially the clouds that produce "water [...] ever stirring in ebbs and flows (continuo fluxu et refluxu reciprocator)." These "clouds over my head" are found to be in "perpetual action (perpetuae activitatis)" and show the reader a beauty of the creation, the "glorious frame (speciosam machinam). ${ }^{155}$ St. Tikhon's first meditation also opens with a sight of the heavens and the beauty of the creation - "observe (smotrish') the heaven, so wonderful, high and wide." Like Hall, St. Tikhon focuses on the motion of the clouds "moving here and there in the air, as water bags (mekhi), streaming out the rain and soaking up our fields." ${ }^{156}$

Among other natural occurrences, both authors highlighted the significance of the "ascending fire (accenso igne)" (Hall) and "the fire, which always ascends (vsegda verkhu idet)" (Tikhon). ${ }^{157}$ So Christians by their very nature, they observed, must always look upward towards God, viewing their various "afflictions" and "discouragements" (Hall) or "obstacles"(Tikhon) as beneficial for the believer's spiritual flame. ${ }^{158}$ Thus, Hall concludes this meditation by praying for God to "flare up (or 'blow up') (adflare)" the "sparks ('gleeds' in old English) of grace (gratiae scintillae)" inside him; Tikhon similarly prays for "God to flare up (vozzhegl) the spark (iskra) of love in your heart."159

The natural imagery of burning continued in the authors' observations of metallurgy: of "the gold melted" (Hall) and "the iron being softened by fire" (St. Tikhon). This sight of the metals melting reminded the authors how a hardened "heart" is softened by "the power of grace (operantis gratiae)" (Hall) or "by God's grace" (Tikhon) ${ }^{160}$ In a similar way, the sight of the light entering a living space inspired the author to contemplate a spiritual meaning of this natural occurrence. Joseph Hall rejoiced, seeing "what a change there is in a room since the light came in (mutates ex quo lumen introit, videtur locus iste - in the Latin edition)." Just like "the light of a poor candle (pauperis lucernae igniculus)" can change the room, the author argues, so the "celestial lamp" can enlighten the believer. ${ }^{161}$ The author ended this observation prayer that God, "the true light shine ever (diffunde radios tuos) through all the blind corners of my soul."162 Tikhon of Zadonsk also begins his meditation by rejoicing to see "candle shining in the room (khramina) or when the day's light shines into it" (Tikhon) and then prays that "this lamp of God's law [...] this divine candle may always shine before us, enlightening (prosveshchaet) us day and night." ${ }^{163}$

Social imagery occupies another important category in the both authors' use of meditative observation. The sight of a "blind man" leads Hall to observe that "many is thus spiritually blind, and because he is so, discerns it not; not disecerning, complains not of so woeful [misera]a condition." ${ }^{\prime 164}$ The same sight leads Tikhon to conclude that one must beware of "a spiritual blindness (slepote dushevnoi), which a sinner possesses, and thus sees not what is good or evil, knows 
not where to go, sees not his ruin (pogibel')."165 At the same time, "the wedding of a young man and a virgin" (Tikhon) or "the sight of the marriage" (Hall) prompts one's memory to recall the "covenant (zavet)" made with God in baptism (Tikhon) or the "union" that the believers have with God by virtue of each soul being "mercifully espoused (desponsasti) to Thyself. ${ }^{166}$

The authors reflected not only on what they saw, but also heard. Thus, Bishop Hall expresses joy at "how sweetly (suaviter) doth this music (concentus or singing choir in Latin edition) sound!" and the "harmonious sounds (harmonici soni)" that he overheard outside of his window, at night. ${ }^{167}$ Pleasant music, Hall argues, should lead a believer to contemplate that "it is no marvel that we cannot fore-imagine (praecogitare) what kind and means of harmony God will have used by his saints and angels in heaven" and then, to think about "the infinite ways to glorify Thyself (te glorificandi)." ${ }^{\prime 68}$ Similarly, Tikhon is overjoyed at hearing "harmonious (soglasnaia) and sweet (sladkaia) music or singing" that reminded him of the "gathering of the angels and saints who offer harmonious (soglasnoe) singing to the Triune God." 69 Tikhon ends his observation with a prayer - "may it happen that you will glorify Him in this life and in the afterlife."170

These parallels and similarities demonstrate that Joseph Hall's work was a likely contributor to the nascent art of spiritual meditation, which appealed to St. Tikhon and his readers. So, the same writings that influenced (according to Huntley) the rise of Puritan devotional literature after the English Civil War, also provided an inspiration for a provincial bishop in Catherinian Russia. On the one hand, this influence seems marginal and Tikhon's work-Sluchai $i$ dukhovnoe ot togo razsuzhdenie - is a relatively small treatise, especially in comparison to his magnum opus. On the other hand, the influence of Anglican devotional literature on a Russian bishop is not ordinary. Finding the impact of Arndt in Tikhon's work is not all that unusual - given the fact how many editions of Arndt circulated in Russia in the eighteenth century and how popular Pietist works were. Finding the echoes of Hall in St. Tikhon is, because Hall's works were not as widely known in Russia. This observation also begs a question of what other Protestant works inspired Tikhon and whether the range of literature that influenced saint's works is much wider than just Johann Arndt and Joseph Hall? Neither of these questions can be answered in the confines of this study but any further work on Protestant influence in the works of St. Tikhon should consider them.

\section{Concluding Remarks}

While this comparative analysis has demonstrated the impact of Protestant devotional literature on the writings of St. Tikhon, such influences are hardly surprising within the general context of the eighteenth-century changes within Russian Orthodoxy. The bishop of Voronezh and the Don was, however, not simply a passive product of his time, a bearer of the intellectual imprint that Feofan Prokopovich, Simon Todorskii and Platon Levshin had impressed upon the church. In the context of extant literature on the post-Schism confessionalization 
in Russia (particularly as described in the works of Aleksandr Lavrov, Gregory Freeze and Robert Crummey), he was also an active agent in the continuing reform of Russian Orthodoxy who found Protestant examples to be particularly useful. ${ }^{171}$ While my 2011 article demonstrated how Protestant models of reform influenced Bishop Tikhon's social disciplining of his Voronezh diocese, this article examined how such models influenced the ways in which the saint reached out to his wider diocese of readers and followers. The bishop's pen inspired his audience to lead a regenerative godly life, to contemplate or meditate in the same mode, genre and style as the confessionalizing Pietist or Anglican hierarchs taught their flocks.

These findings presented in this paper also shed a new light on the development of Orthodox theology, monastic beliefs, and religious devotion in Catherinian Russia. They raise a larger question about the much-acclaimed monastic revival of the latter part of the eighteenth century, especially its intellectual stimuli and inspiration. Likewise, Tikhon's adaptation of Western devotional models further reveals that that the boundaries of piety and religious thought between Russia and Enlightenment-era Europe were hardly rigid. There was greater intellectual interaction between Russian Orthodoxy and the Protestant West than has been acknowledged so far, a penetration of ideas that spanned not only theology but also the sublime and sacred spheres of personal and monastic spirituality. 


\section{APPENDIX 1 \\ Examples of textual parallels between the True Christianity works of Arndt and St. Tikhon.}

Table 1

Motivations to Repentance by Johann Arndt, Chtiri Knigi, 502-8

1. Милосердие Божие

Господь бо Бог твои есть милосердный Бог, не оставит тя ниже погубит тя, ниже забудет завета им же клятся отцем твоим.

Не подобает нам презирати ему милосердия сердца отеческаго, на покаяние призирающаго.

\section{2. Христово благоприятие}

Ниже точию благосердие Христово возбуждает тя к покаянию, но и сердечная Его печаль, и святая Его пролитая кровь вопиет к тебе сице:

Помяни яко аз непредал тебе, ради неба, ниже земли ради, но ради души твоея, ты же хочешь самовольным непокаянием своим сокровище свое погубити.

Помяни яко не иним же искупления златом искупитися тебе мощно, бе токмо единою кровию христовою. 1 Петра 1, 19.

Помяни, коликою тяжесть Создатель твои ради тебе претерпел, коль рыдал, тужил, трепетал и ужасался, коль страшно ради твоих грехов уязвлен был како он червом и клятвою на древе сотворился. О препечальное позорище! О прежалостное видение покаяния!
Motivations to Repentance by Tikhon of Zadonsk, Tvoreniia, T. II, 201-4

\section{1. Великое Божие хотение спасения} нашего

Видишь из прешедшего параграфа, и прочих пророрческих и апостольских увещаний примечается, которыя отеческое Божие сердце и великое нашего спасения желание открывают.

Не подобает убо нам так великаго милосерднаго Бога хотения презирать, но обратиться и каяться.

\section{2. Чудное Сына Божси о нас смотрение}

Помяни како скорбел, тужил, ужасался, кровавым обливался потом: ты же не хочешь потужити, поскорбети и поболети о грехах твоих.

Како страшно поруган, посмеян, оплеван, заушен и уязвлен был ради тебе.

Како ужасно мучен, распят, посреде разбойников повешен, ко кресту прогвожден, и безчестно ради тебе умер.

Не истленным сребром или златом избавихомся от суетнаго жития нашего, отцы преданного но честною кровию, яко Агнца непорочна и честна Христа. 1 Петра 1, 17-19

Самая кровь Его вопиет к нам, да престанем от грехов и покаемся. 


\section{3. Прещение временныя мукы}

Бог судитель праведен и крепок. Аще не обратитеся, оружие Свое очистить, лук Свой напряже и уготова, и в нем уготови сосуды смертныя, стрелы своя с горящими содела.

Понеже от гнева и ярости Божия никто же может убежати. Аще взиидуть на небо, оттуда низведу их, аще сокриются в глубине морской, повелю змием тамо угризати их.Ам 9, 1,2,3.

Покаяние отвращает казнь от земли, погубление некоего народа, града или царствия, якоже в Ниневии повествовалося.

\section{Внезапно глаголю аз противу некоего} народа, воеже потребити и погубити его, ащеже обратитеся, раскаюся, яко помыслих сотворити ему зло. Иерем. 18,7 .

\section{4. Смерть.}

Сего ради Бог час смертный неизвестен сотворил, дабы мы повсяк день и на всякое время творили покаяние, и всякий час аки последний час внимали.

Благодать Свою Бог обещал тебе, но утрешнего дня не обещал.

Яко же обретет тебе Бог, тако и осудит тя. Сего ради долженствуеши в житии твоем такоб быти какова быти тя желаеши в час смерти твоея.

\section{5. Остатнии суд.}

Нехотящемуже каятися страшное оное услышает изречение: идите от мене проклятии во огнь вечный.

\section{3. Прещение Божие}

Бог претит казнию некающимся. Аще не обратитеся, оружие Свое очистит, лук Свой напряже, и уготова его, и в нем уготова сосуды смертныя, и проч.

И сокрыться от Него нигде невозможноь везде сретает отмщение Его некающихся...аще взыдут на небо, то и оттуду свергу яь и аще скрыются на верс кармила, то и оттуду взыщу и воз ьму я и аще погрузятся от очию Моею во глубинах морских, то и тамо повелю змиеви, и угрызет я, и проч. Амос 9, 2, 3

К сему безопасному убежищу прибегли Ниневитяне, послушавши грядущий гнев Божий и сокрылися, и тако спаслися.

Возглаголю на язык и на царство, да искореню их, и разорю, и расточу я. И аще обратится язык той от всех лукавств своих, то раскаюся о озлобленияхь яже не мыслих сотворити их. Иерем. 18, 7-8.

\section{4. Кончина жития нашего}

Поощряет нас к покаянию неизвестная кончина жития нашего, которая неотменно будет, но когда будет, неизвестно.

Бог обещает нас принять кающихся, подать отпущение грехов, но утрешняго дня не обещает.

Каковыми застанет нас смертный час, таковыми и пред судом Его явимся. И потому каковым хощешь умрети, таким должен еси и во всем житии быти.

\section{5. Страшный суд Христов}

Страшный суд Христов да подвигнет нас к покаянию, на котором всем нам -Всем, праведным глаголю и грешным, явитися подобает и воздати о содеянных 


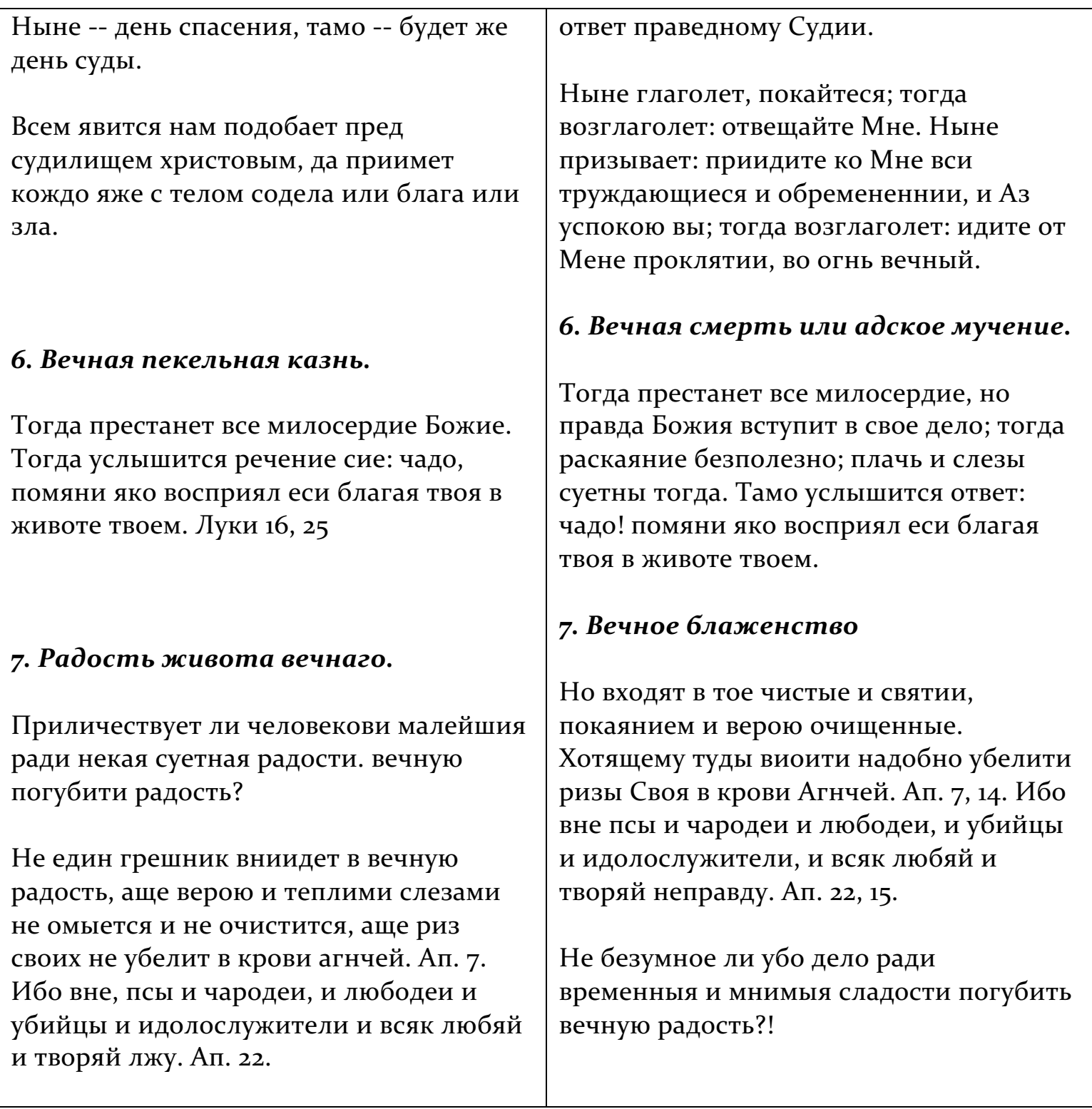


Table 2

\section{USE OF RHETORICAL IMAGES IN ARNDT AND TIKHON OF ZADONSK}

\begin{tabular}{|l}
\hline \multicolumn{1}{|c}{ Johann Arndt } \\
\hline \multicolumn{1}{|c}{ CHILD } \\
Вера бо в человеке есть, аки некое \\
новорожденное отроча стоящее наго \\
без всекаго прикрытия, пред \\
спасителем своим и избавителемь вся \\
сия есть оправдание, благочестие, \\
святость и Духа Святаго. \\
Таковоя нагое никакого же \\
покровения не имеющое отроча \\
Божиим милосердием покрывается; \\
воздевает руце свои горе и \\
воспринимает вся от Бога. (33) \\
\hline
\end{tabular}

\section{DOCTOR}

Убо долженствует первее в познание немощи нашея приити: понеже здравии врача не требуют но болящи. Вси же сии духовныя своея немощи не познают, которые без истиннаго покаяния живут, сердечныя печали ради грехов своих не творят, сердца смиреннаго и сокрушеннаго не имеют (64-65).

\section{SEA}

Мир сей морю подобный есть, якоже бо море содержит в себе точию живущая, все же мертвое извергает из себе -- тако и мир сей всякаго умершаго похотем своим извергает и изганяет вон: аще кто благополучное, исполненное гордости и суетния славы житие провождает, сей мирови чадо прелюбезное есть (111).

\section{Tikhon of Zadonsk}

Паки уподобляется малому отроку, который наг стоит пред материю своею и просит одеяния: тако грешник, обнажен одежды правды и спасения, стоит и ищет прикрытия наготе своей, но не может сыскати. Таковая одежда, одежда оправдания, открывается и показуется ему во Евангелии, которая есть правда Христова, которую верою туне приемлет, и покрывается нагота его и срамота. (II, 8)

Ибо кто не видит своея немощи и не признает, тот и врача не ищет, но единии болящии, которые болезнуют сердцем, сердце стрелою греха и печали уязвленное имеют. Не требуют бо здравии врача, но болящии, глаголет Христос (II, 9).

Сказуют, что море содержит в себе живых только животных, а мертвых извергает вон из себе; тако бывает в море мира сего. Кто миру и прихотям мира живет, сей миру любезное есть чадо, а кто отреклся и умер ему, сего извергает и изгоняет вон из себе (II, 247). 


\begin{tabular}{|c|c|}
\hline $\begin{array}{l}\text { MIRROR } \\
\text { Паки подобная есть [душа] зерцалу, } \\
\text { якожебо зерцало к нему же } \\
\text { обратится, сие в нем и видится: аще } \\
\text { будет обращенное к небеси, небо в } \\
\text { нем видится; ащеже к земле, земля в } \\
\text { нем видится; тако и душа } \\
\text { человеческая, к коелибо вещи } \\
\text { обратится, сея и образ в нем уздрится } \\
(164) \text {. }\end{array}$ & $\begin{array}{l}\text { Образ Божий должен зреться в душе } \\
\text { твоей, как в зеркале, которое куда } \\
\text { обратишь, то в нем и увидишь. Если } \\
\text { ты обратишь зеркало к небу, то } \\
\text { увидишь в нем небо; если обратишь } \\
\text { его к земле, то увидишь в нем землю } \\
\text { (I, 2о9). }\end{array}$ \\
\hline
\end{tabular}

Table 3

Examples of content similarities between Joseph Hall's Occasional Meditations and Tikhon of Zadonsk's "Sluchai i dukhovnoe ot togo razmyshlenie"

Texts: Josephi Halli Exoniensis Episcopi. vel, Meditatiunculae subitaneae (London: Impensis Nath. Butter, 1635) and "Sluchai i dukhovnoe ot togo razmyshlenie" in Tvoreniia II, 15-108.

\begin{tabular}{|l|l|}
\hline $\begin{array}{l}\text { Vocative terms, used to summon the } \\
\text { reader to focus on the subject of } \\
\text { meditation. }\end{array}$ & $\begin{array}{l}\text { Vocative terms, used to summon the } \\
\text { reader to focus on the subject of } \\
\text { meditation. }\end{array}$ \\
$\begin{array}{l}\text { Select examples from Meditatiunculae } \\
\text { subitaneae... }\end{array}$ & $\begin{array}{l}\text { Select examples from Sluchai } i \\
\text { dukhovnoe ot togo razmyshlenie... }\end{array}$ \\
\hline Ecce: XI, XXVII, XXIXXXXVIII LII; and & Видишь: meditations II-XVXXIX-XLVIII, \\
LXIV,CXXXIV & LIII-LXIIII,C-CIV \\
Videre (vide, video, vidi): XLV, LIII, LXIII, & Слышишь: XXVI, LIII, LX \\
LXXXIII, & Смотришь: I \\
Audi: XLVII & Знаешь ли: XCIX, CIX \\
Intueror: CI, CIV, CXXXII & \\
\hline
\end{tabular}


Nescio: LXV, LXXI, LXXIII, LXXV, LXXXIV

\section{Objects of meditations:}

Select examples from Meditatiunculae subitaneae... and Sluchai i dukhovnoe ot togo razmyshlenie...

\section{Heavens}

I.Conspecto caeli motu. Nihil quicquam

præter terram quiescere video: cætera quæque motu perpetuo agitantur. Etiam et aqua illa, quæ unum cum terrà globum constituit, continuo fluxu et refluxu reciprocatur: nubes, supra caput volitantes; supra nubes, coelum ac sydera; sic aguntur perpetim: hæc, uti præ cæteris eminent conspicua, ita nobis exempla præferunt perpetuæ activitatis.

Quid tandem æmulemur nos æquè, ac speciosam hanc mundi machinam?

I.Смотришь на небо, так чудное, высокое и обширное, различными звездами украшенное; на солнце и луну сияющия и всю поднебесную осиявающия; на облака, в воздухе туды и сюды преходящия, и, как мехи, дождь точащия и напояющия нивы наши.

Да будет тебе случай сей удивлятися: 1) всемогуществу Бога нашего, Который вся сия из ничего словом единым сотворил 2) премудрости Его, Который так премудро сотворил;

\section{Light in the room}

XX. Lucerna introducta.

Quantum vero mutatus, ex quo lumen introiit, videtur locus iste! imo, et nos ipsi! Omnia profecto novam formam, et vitam quasi novam induisse visa sunt: neque nos ipsi iideni sumus. Quam pulchra res lux est!

Quod si pauperis lucerna; igniculus, qui nihil aliud est nisi pauxillum inflammati aeris fuliginosi cujusdam lini oleaginosae pinguedini circumfusi, ita oculos animumque afficiat; quanto magis gloriosis solis radiis, coelestis lampadis splendore delectamur!

O tu, qui solus es Vera Lux, diffunde radios tuos per caecas omnes animae meae latebras anfractusque....
LVII. Когда свеща в храмине светит, или свет дневной просвещает, тогда все видишь ясно, и едино от другаго распознаешь, что вредно и что не вредно.

Подобно бывает и тому, которому светильник закона Божия всегда сияет, и умныя его просвещает очи, якоже глаголет Псаломник:

«светильник ногама моима закон Твой, и свет стезям моим» (Пс. 118:105).

Когда сия божественная свеща всегда сияет пред нами, и просвещает нас день и нощь, всегда как во дни ходити будем, и добро от зла, пользу от вреда, и добродетель от порока распознавать... 


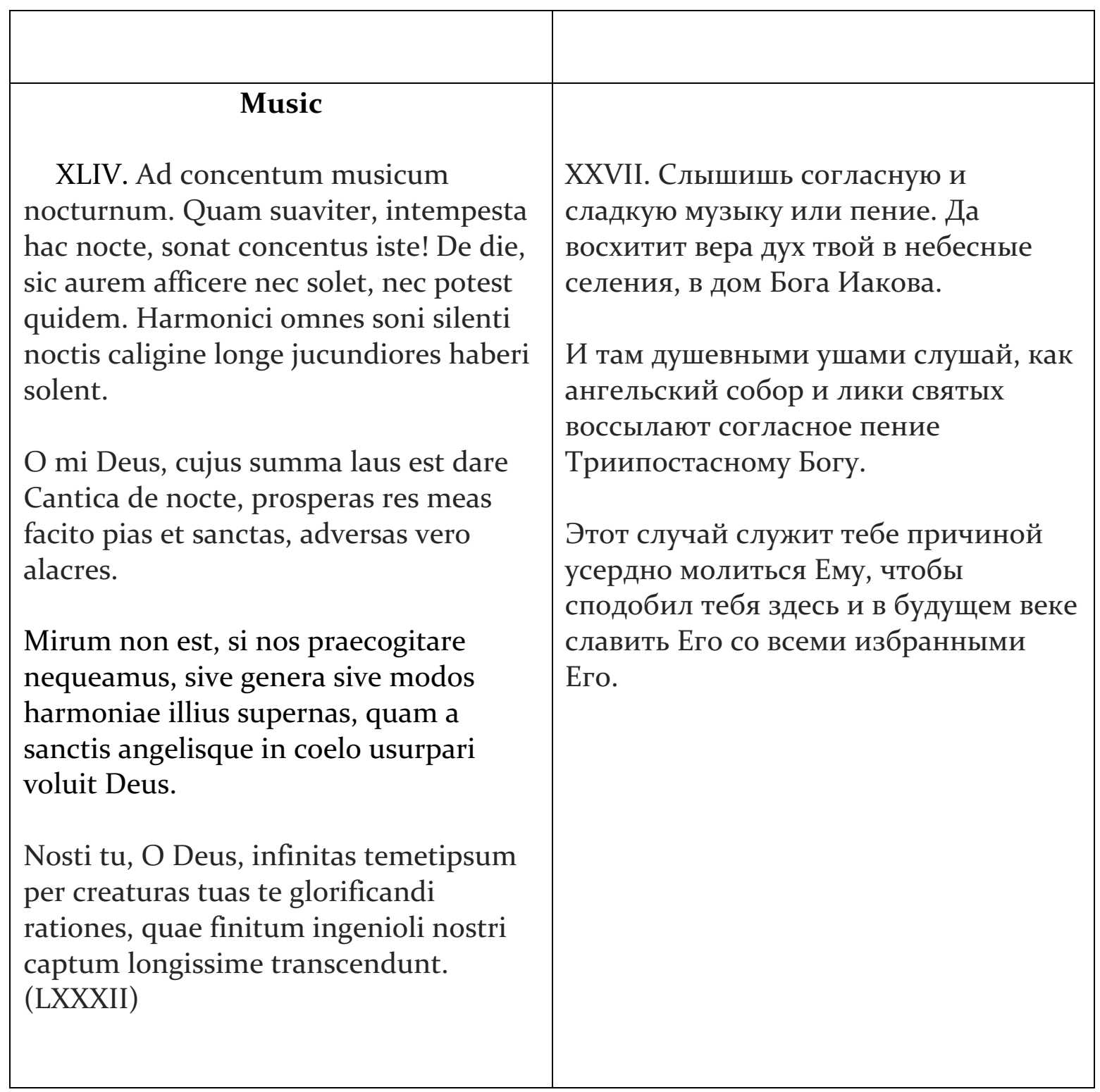




\section{APPENDIX 2 - IMAGES}

Fig. 1: Portrait, St. Tikhon of Zadonsk. Image source: Tikhon (Sokolov), St. Tvoreniia izhe vo sviatykh ottsa nashego Tikhona Zadonskogo vol 1. (Moscow: v Sinodal'noi tipografii, 1889), second cover page.

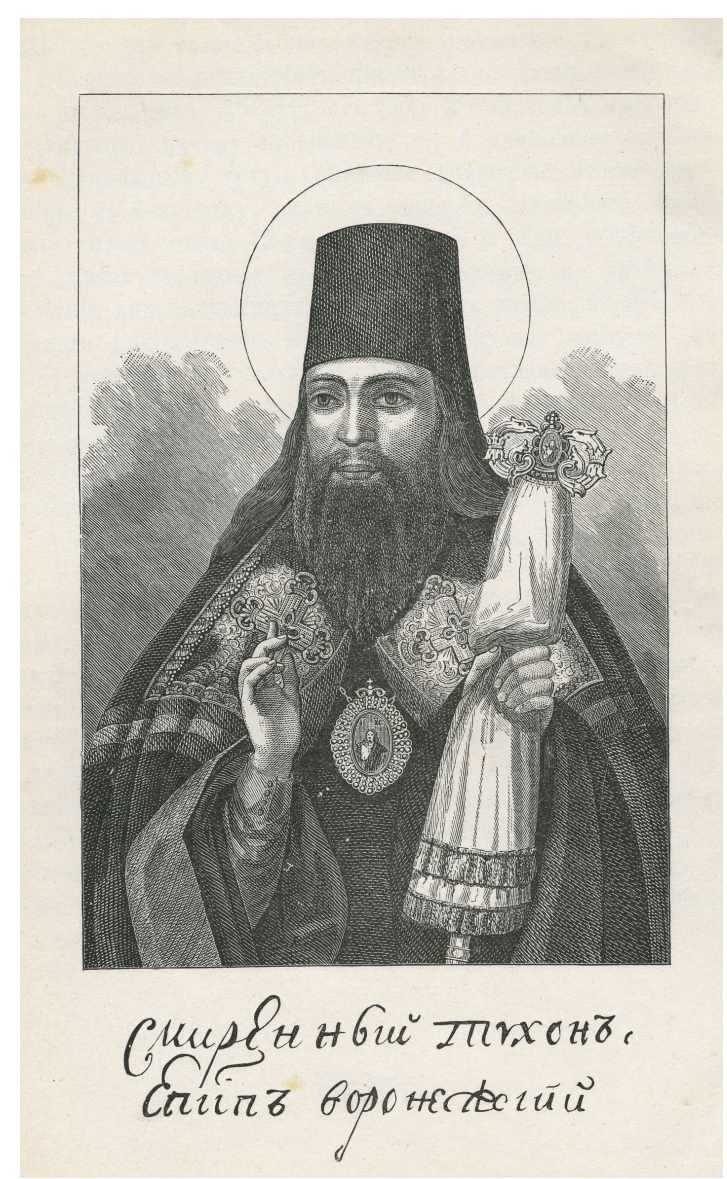

Image courtesy of Sterling Memorial Library, Yale University. 
Fig. 2: Chtiri knigi o istinnom Khristianstve. (Halle, 1735). Simon Todorskii's translation of Johann Arndt's Wahres Christentum. Image source: Johann Arndt, Chtiri knigi o istinnom Khristianstve...slozhennyi chrez Ioanna Arnda, z nemetskago iazyka na russkii perevedennyi i napechatannyi. (Halle, 1735). Title page.

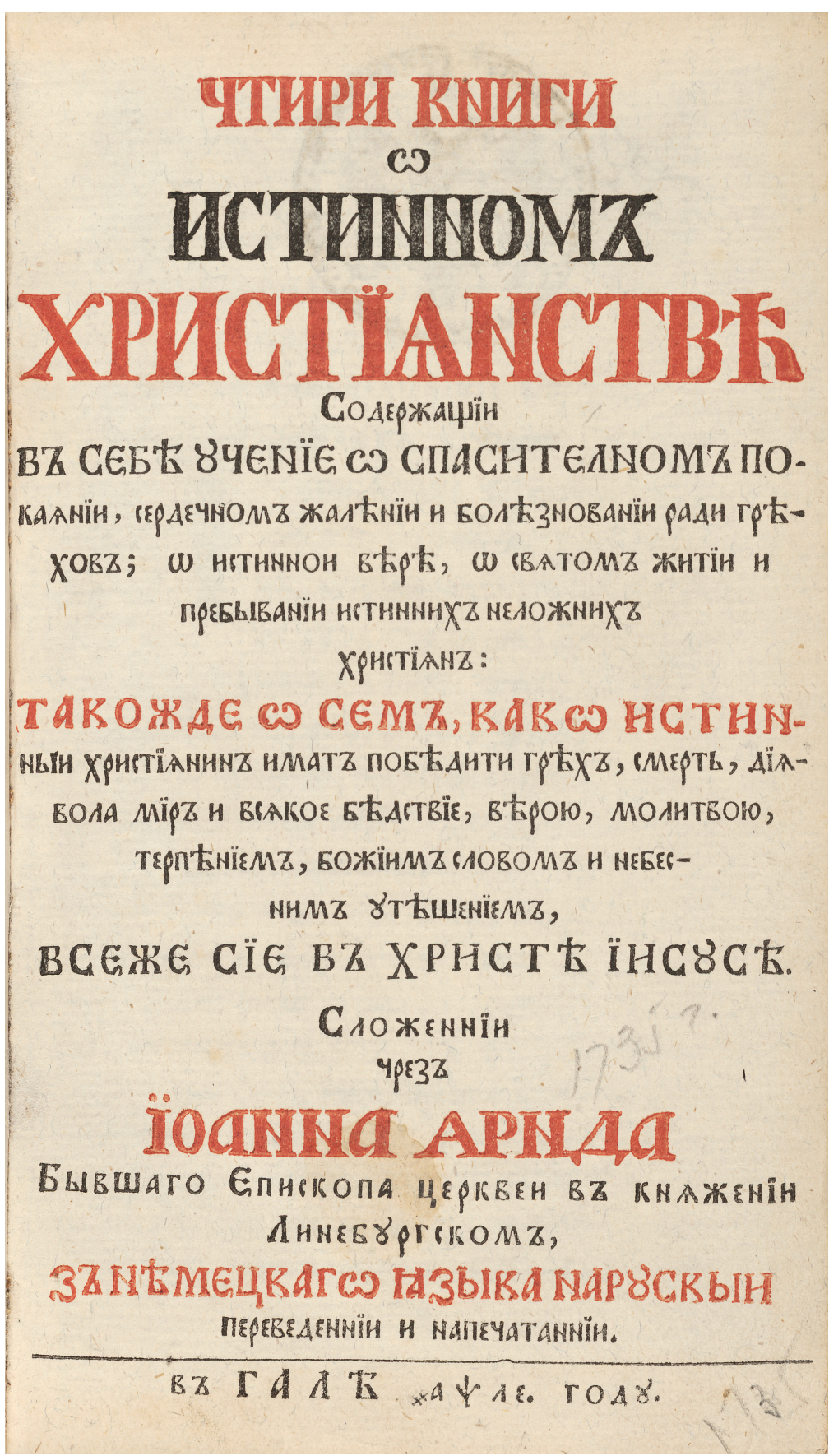

Courtesy of Beinecke Rare Book and Manuscript Library, Yale University. Scanned by Beinecke Rare Book and Manuscript Library, Yale University. 


\section{ENDNOTES}

${ }^{1}$ Fedor M. Dostoyevsky, Pis'ma 1867-1871, vol. 2 (Moscow-Leningrad: Gosudarstvennoe izdatelstvo, 1930): 263-264. An earlier version of this article was presented at "Sources First! Religion, Politics and Culture in Pre-Modern and Modern Russia" conference held on April 4-5, 2008, at Yale University, New Haven, CT. I would like to thank conference participants, particularly Paul Bushkovitch, Nikolaos Chrissidis, Nikolai Firtich and Vera Shevzov for providing valuable comments and suggestions on the draft of the paper. I am grateful to Carlos Eire, Serhii Plokhii, and Douglas Shantz for sharing their remarks on the parallels of St. Tikhon's thought to the Western and Central European religious context. I would also like to thank the Beinecke Rare Book and Manuscript Library and Smith Richardson Foundation at Yale for providing research support for this article through the summer fellowship programs. I am especially grateful to the support of Herzog August Bibliothek's fellowship (Vollstipendium) in the summer of 2016 that enabled me to become better acquainted with the Pietist connections to Eastern Orthodox churches and with the Protestant devotional literature that was read and (often) translated in eighteenth century Russia.

${ }^{2}$ Margaret Ziolkowski, "Dostoevsky and the kenotic tradition," in George Pattison and Diane Oenning Thompson, eds., Dostoevsky and the Christian Tradition (New York: Cambridge University Press, 2001): 34-36; Thomas Berry, "Dostoevsky and St. Tikhon Zadonsky" in New Zealand Slavonic Journal (1989-1990): 67-72. On the relationship of St. Tikhon and Dostoevsky's works see Nadejda Gorodetzky, Saint Tikhon Zadonsky, Inspirer of Dostoevsky (London: SPCK, 1951).

${ }^{3}$ N. Sergievskii, Sviatitel' Tikhon: episkop voronezhskii $i$ zadonskii $i$ vseia Rusi chudotvorets (Moscow: Tipografiia Vysochaishe utverzhd. T-va I. D. Sytina, 1898):3.

${ }^{4}$ Nicholas Berdiaev, “Sushchestvuet li v Pravoslavii svoboda mysli i sovesti?" Put' 59 (1939): 46-50.

${ }^{5}$ Georgii P. Fedotov, Sviatye drevnei Rusi (Moscow: Moskovskii rabochii, 1991): 111-131.

${ }^{6}$ Innokentii Nechaev was a serf of the Naryshkin estate and remained friends with Naryshkins even after his education at Moscow Academy. A. V. Naryshkin was governor of Pskov when Innokentii was Pskov's bishop. He was buried next to the Naryshkins in the Alexander-Nevsky Lavra. Innokentii was claimed by Catherine II to be along with Gavriil and Platon the brightest of all the hierarchs. RBS, Vol. 8, 118-119; A. P. Dmitriev, Istoriia Korel'skoi (Keksgol'mskoi) eparkhii (Priozersk: IP Kompleks, 2000); Simon Lagov, Archbishop of Riazan' was born a monastery serf, but distinguished himself through voice by joining Bp. Amvrosii Iushkevich's boy choir in 1736, from where he continued his education to Moscow. Zdr. (sic), "Simon (v mire, Stefan Lagov)," RBS, 18:498-499.

${ }^{7}$ Andrey Ivanov, “The Saint of the 'Russian Reformation': St. Tikhon of Zadonsk and the Impact of Protestantism in Eighteenth Century Orthodox Church", in Cathy Potter, Jennifer Spock, Nikolaos Chrissidis, eds. Religion and National Identity in Russia and the Soviet Union (Bloomington, IN: Slavica Press, 2011): 81-106.

${ }^{8}$ Alfred Beutel, Aufklärung in Deutschland (Göttingen: Vandenhoeck \& Ruprecht, 2006): 228.

9 B. Krupnyts'kyi, “Teofan Prokopovych i shvedy," Zapysky Chyna sv. Vasyliia Velykoho 4 (1934): 297. For more on Pietist connections to Orthodox hierarchs in Russia, see "Brief von Gottfried Himler an Gotthilf August Francke. 19.04.1727," AFSt Film Stab/F 29/31:1. "Brief von Christian Haumann an [Ernst Salomon Cyprian]. 08.09.1720," AFSt/H A 174:150 ss. 3-4; Johann Christoph von Dreyhaupt, Pagus Neletici et Nudzici oder ausfuehriche diplomatisch- historische Beschreibung des ... Saal-Creyses ..., Bd. 2 (Halle 1755): 173; Theodor Wotschke, "Pietismus in Moskau," Deutsche Zeitschrift für Polen 18 (1930): 53-95; and a reference in Acta historico-ecclesiastica oder gesammelte Nachrichten von den neuesten Kirchen-Geschichten 9 (Weimar, 1745): 655. On the biography of Haumann see, Eduard Winter, Halle als Ausgangspunkt der deutschen Rußlandkunde im 18. Jahrhundert (Berlin: Akademie-Verlag, 1953). 175. For the German Protestant polemics in favor of Feofan's reforms in Russia, see J. F. Buddeus, Epistola Apologetica Pro Ecclesia Lutherana contra calumnias et obtrectationes Stephani Javorskii (Jena, 1729), 67, 2-4; J. T. Jablonski, Genius Stephani Jaworscii quondam Metropolitae Rezanensis \& Muroniensis ex eius opere posthumo 
theosophico Petra fidei dicto in epistola familiari develatus (S. I., 1730), 7-8 (on reassurances of independence of the Russian Church from Lutheran Church), 13 (on the dangers of Iavroskii's faction); Johann B. Mencken, "Stephanii Iavorscii....Petra fidei," Acta eruditorum publicata Lipsiae (May 1729): 226-229 (on Papal designs for Russia as supported by the bishops of lavorskii's faction).

${ }^{10}$ Winter, Halle als Ausgangspunkt der deutschen Russlandkunde im 18. Jahrhundert, 31-39, 99-104, 120-146.

"A. B. Shishkin, "Simon Todorskii," Online Publication of the Russian Academy of Sciences (Pushkinskii Dom), available at www.lib.pushkinskijdom.ru/LinkClick.aspx (Last Accessed: 28 May 2012). The title of his translation of Johann Arndt is Chtiri knigi o istinnom khristianstve, trans. Simon Todorskii (Halle [v Gale magdeburgskoi], 1735). He also translated a number of hymns popular with the Pietists, including the Te Deum Laudamus, and the hymns by M. Rutinius, J. Francke, F. Nikolai, as well as S. Weingertner.

${ }^{12}$ The 1735 version was published in Halle, translated from the German language. The 1784 and 1800 editions were likewise translated from the German, but published in Russia. The 1790 edition was translated from English and dedicated to Potemkin, as it was printed at the prince's campaign headquarters in Iassy, Moldavia. Iurii Bitovt, Redkiia russkiia knigi i letuchiia izdaniia XVIII veka (Moscow: Tip. S.P. Semenova, 1905; Reprint: 1989): 406, 454, 535.

${ }^{13}$ See the conclusion of this article for brief discussion of confessionalization and how it may apply to the works of St. Tikhon.

${ }^{14}$ Simon Todorskii, "Predoslovie," in Johann Arndt, Chtiri knigi o istinnom khristianstve (Halle, s. n., 1735): 2. Todorskii was actually the first translator of Johann Arndt into Church Slavic (from the 1726 Basel German edition) and one of the first Russian alumni of Halle.

${ }^{15}$ Tikhon of Zadonsk, Tvoreniia izhe vo sviatykh ottsa nashego Tikhona Zadonskago V (Moscow: v Sinodal'noi tipografii, 1889; Reprint: Izdanie Sviato-Uspenskogo Pskovo-Pecherskogo monastyria, 1994), 331. This letter (No. 31) in Tikhon's collection of correspondence is not addressed to a particular addressee but written as a general exhortation, characteristic of many of the saint's letters from the period.

${ }^{16}$ Georges Florovsky, Puti russkogo bogosloviia (Paris: YMCA Press, 1983), 123.

${ }^{17}$ In "Primechaniia," Tikhon of Zadonsk, Tvoreniia III (1889 edition), p. ii.

${ }^{18}$ Florovsky, 123-125; Gorodetzky, Saint Tikhon Zadonsky, Inspirer of Dostoevsky, 95-117; Pavel Khondzinskii, "Dva truda ob istinnom khristianstve: Sviatitel' Tikhon Zadonskii i Iogann Arndt," Zhurnal Moskovskoi Patriarkhii No. 2 (2004); Elisabeth Behr-Siegel, "Hesychasm and the Western Impact in Russia: St. Tikhon of Zadonsk (1724-1783)," in Louis Dupre and Don Saliers, eds., Christian Spirituality: Post-Reformation and Modern (New York: Crossroad, 1989): 440-445.

${ }^{19}$ Indeed, seventeenth and eighteenth centuries saw such a mass proliferation of popular spiritual manuals on meditation or piety in Europe that certainly merit the name of "Baroque spirituality." The issue of the applicability of this concept to Russia is outside of the scope of this research.

${ }^{20}$ Iurii F. Samarin, "Stefan Iavorskii I Feofan Prokopovich," in Sochineniia Vol.V (Moscow: Tipografiia A. I. Mamontova I Ko., 1880): 42-47.

${ }^{21}$ Samarin, "Stefan Iavorskii," 135-137; Florovsky, Puti, 93.

${ }^{22}$ Samarin, "Stefan Iavorskii," 111-114; Samarin here used Prokopovich's treatise De corruptione voluntatis published in Christianae Orthodoxae Theologiae in Academia Kiowiensia Theophane Prokopovicz (Lipsiae: ex officina Breitkopfia, 1792-1793).

${ }^{23}$ Tikhon of Zadonsk, Tvoreniia izhe vo sviatykh ottsa nashego Tikhona Zadonskago, III (Moscow: v Sinodal'noi tipografii, 1889; Reprint: Izdanie Sviato-Uspenskogo Pskovo-Pecherskogo monastyria, 1994): 305. Henceforth, all works by Saint Tikhon of Zadonsk will be abbreviated as Tikhon, followed by the volume and page numbers.

${ }^{24}$ Johann Arndt, Chtiri knigi o istinnom khristianstve, 3-4; Compare, for example, Tikhon's (Tvoreniia I, 209) metaphor of the mirror and the image of God in man against the virtually identical Arndt's (Chtiri knigi, 164) in the appendix.

${ }^{25}$ Arndt, Chtiri knigi, 4, 11. 
${ }^{26}$ Tikhon, Tvoreniia II, 126.

${ }^{27}$ Ibid., 117.

${ }^{28}$ Ibid.

${ }^{29}$ Arndt, Chtiri knigi, 11.

${ }^{30}$ Ibid., 494.

${ }^{31}$ Ibid., 494-495.

${ }^{32}$ Ibid., 12-13.

${ }^{33}$ Ibid

${ }^{34}$ Ibid., 14.

${ }^{35}$ Tikhon, Tvoreniia III, 7 .

${ }^{36}$ Ibid., 9.

${ }^{37}$ Arndt, Chtiri knig, 64. "Христос Господь представляет нам себе аки некоего врача," he stated.

${ }^{38}$ Ibid., 64-65.

${ }^{39}$ Ibid., 33 .

${ }^{40}$ Ibid., 31-32.

${ }^{41}$ Ibid., 32-33.

${ }^{42}$ Ibid.

${ }^{43}$ Tikhon, Tvoreniia III, 8.

${ }^{44}$ Ibid., 8

45 Ibid., 8. In the Slavonic version of Arndt's book term "pravda" is used as well, although both authors also use more specific expressions like "opravdanie" (justification) and "pravednost" (righteousness).

${ }^{46}$ Ibid. The idea of inhabitation (Einwohnung) of God's essence in a regenerated Christian has been a hallmark of Spener's theology, but may in some ways be connected to Spener's reading of the Greek Fathers. For further discussion, see Martin Schmidt, Wiedergeburt und Neuer Mensch (Witten: Luther-Verlag, 1969):169-194.

${ }^{47}$ Tikhon, Tvoreniia III, 9.

$4^{8}$ Ibid., 23.

${ }^{49}$ Tikhon, Tvoreniia III, 49-50; Arndt, Chtiri knigi, 39-40; Martin Luther, Luther's Works vol. ${ }_{11}$ (St. Louis: Concordia Publishing House, 1955-1986): 29.

${ }^{50}$ Philip Jacob Spener, Pia Desideria, trans. Theodore G. Tappert (Philadelphia: Fortress Press, 1964): 65-66; On official Lutheran position vis-à-vis baptism and new birth see, Hermann Cremer, Taufe, Wiedergeburt und Kindertaufe in Kraft des heiligen Geistes (Gütersloh: C. Bertelsmann, 1901); Schmidt, Wiedergeburt und Neuer Mensch. On the orthodoxy of Arndt, see Christian Braw, Bücher im Staube. Die Theologie Johann Arndts in ihrem Verhältnis zur Mystik (Leiden: E. J. Brill, 1986). Also, see Jonathan Strom, "Problems and Promises of Pietism Research," Church History 71:3 (Sept. 2002): 536-554.

${ }^{51}$ Philip Jacob Spener, Pia Desideria, 66.

${ }^{52}$ For general notions of Pietist thought within the larger Lutheran context, see John T. McNeil Modern Christian Movements (New York: Torchbook/Harper\&Row, 1968): 15-103; Hans-Martin Rotermund, Orthodoxie und Pietismus (Berlin: Evangelische Verlagsanstalt, 1960): 7-12; T. G. Tappert, "Orthodoxism, Pietism and Rationalism: 1580-1830," in Harold C. Letts, ed. Christian Social Responsibility, Vol. 2. (Philadelphia: Muhlenberg Press, 1957): 36-88; Jaroslav Pelikan, The Christian Tradition, Vol. 5: Christian Doctrine and Modern Culture (since 1700). (Chicago: University of Chicago Press, 1989): 4-18. Also, recent research, such as Hans Schneider, Der fremde Arndt. Studien zu Leben, Werk und Wirkung Johann Arndts (Göttingen: Vandenhoeck \& Ruprecht, 2006); Martin Brecht et al. eds., Geschichte des Pietismus, 4 vols. (Göttingen: Vandenhoeck \& Ruprecht, 19922004); Johannes Wallmann, Der Pietismus (Göttingen: Vandenhoeck \& Ruprecht, 2005) and Richard Gawthrop, Pietism and the Making of $18^{\text {th }}$ century Prussia (Cambridge: Cambridge University Press, 1993).

${ }^{53}$ Tikhon, Tvoreniia III, 49-51. 
${ }^{54}$ Arndt, 21. As a goof Lutheran Ardnt believed the spiritual regeneration to originate in "the washing regeneration of baptism" (29).

55 Tikhon, Tvoreniia III, 51.

${ }^{56}$ Tikhon, Tvoreniia III, 50.

${ }^{57}$ Tikhon, Tvoreniia III, 51-52.

${ }^{8}$ Arndt, Chtiri knigi, 16, 20. Compare Tikhon's statement, “Понеже в человеке, который христианскую веру и крещение восприял, ветхое или плотское, новое или духовное рождение и потому два рождения имеются." (Tvoreniia III, 50) against Arndt's “ Человек, христианскую веру восприявшии, двоякое имеет рождение, единое ветхое, плотское...второе же рождение духовное, святое, блаженное, новое." (Chtiri knigi, 2о).

${ }^{59}$ Arndt, Chtiri knigi, 23.

${ }^{60}$ Ibid., 23-24

${ }^{61}$ Ibid., 20, 70.

${ }^{62}$ Ibid., $510-511$.

${ }^{63}$ Ibid., 512-513.

${ }^{64}$ Tikhon, Tvoreniia II, 197.

${ }^{65}$ Ibid., 198. Arndt, 498-499.

${ }^{66}$ Tikhon, Tvoreniia II, 204.

${ }^{67}$ Ibid., 204.

${ }^{68}$ Arndt, Chtiri knigi, 499-500.

${ }^{69}$ Ibid., 500-501.

$7^{70}$ Ibid., 501: “О милосердних очес отеческих, коль усердно взирають на погибшаго сына!" Compare against Tikhon's statement: “когда видит Бог, Отец небесный, -- о коль благоприятно смотрит на него! как мил бывает святым и милосердным очесам Его!” (Tvoreniia II, 205).

${ }^{71}$ Arndt, Chtiri knigi, 501; Tikhon, Tvoreniia II, 201.

${ }^{72}$ Arndt, 502-508; Tikhon, Tvoreniia II, 201-204. See appendix for the detailed comparison of passages.

${ }^{73}$ Arndt, 502-508; Tikhon, Tvoreniia II, 201-204. See appendix.

${ }^{74}$ Ibid.

${ }^{75} \mathrm{Ibid}$.

${ }^{76}$ Ibid.

${ }^{77}$ Ibid.

${ }^{78}$ Ibid.

79 Tikhon, Tvoreniia III, p. 50, 57; Arndt, Chtiri knigi, 490.

${ }^{80}$ Tikhon, Tvoreniia III, 57-59; Arndt, Chtiri knigi, 498. On Arndt's idea of the "fruits" and Nachfolge in Christian devotion, see Braw, Bücher im Staube, 97-102, 140-142.

${ }^{81}$ McNeil, Modern Christian Movements, 98-105; Jakob Phillip Spener, Pia Desideria, 97-91.

${ }^{82}$ Ibid., 246.

${ }^{83}$ Ibid., 246.

${ }^{84}$ Arndt, Chtiri knigi, 115.

${ }^{85}$ Tikhon, Tvoreniia II, 247; Arndt, vol. 1, 76-77.

86 "prishelets i strannik" in both Arndt, 102; and Tikhon, Tvoreniia II, 251.

${ }^{87}$ Tikhon, Tvoreniia II, 256, 259-261; Arndt, Chtiri knigi, 163-165.

${ }^{88}$ Tikhon, Tvoreniia I, 107.

${ }^{89}$ Tikhon, Tvoreniia II, 255.

${ }^{90}$ Both use the 1 John 2:15 passage: Arndt, Chtiri knigi, 27; Tikhon, Tvoreniia II, 256.

${ }^{91}$ Arndt, Chtiri knigi, 235, obvious play on words, gor'ko, gorest.'

${ }^{92}$ Ibid., 235-236.

93 Tikhon, Tvoreniia II, 256-26o.

${ }^{94}$ Ibid., 26o.

${ }^{95}$ Arndt, Chtiri knigi, 232-235; Tikhon, Tvoreniia III, 255. 
${ }^{96}$ Tikhon, Tvoreniia II, 311; Arndt, Chtiri knigi, 177; Tikhon, Tvoreniia II, 317-318; Arndt, Chtiri knigi, 173-176.

${ }^{97}$ Tikhon, Tvoreniia II, 312.

${ }^{98}$ Tikhon, Tvoreniia II, 312.

${ }^{99}$ Arndt, Chtiri knigi, 248.

${ }^{100}$ Ibid., 248-249.

${ }^{101}$ Ibid., 452.

${ }^{102}$ Tikhon, Tvoreniia II, 312.

${ }^{103}$ Arndt, Chtiri knigi, 249.

${ }^{104}$ Tikhon, Tvoreniia II, 313.

${ }^{105}$ Arndt, Chtiri knigi, 179; Tikhon, Tvoreniia II, 336.

${ }^{106}$ Arndt, Chtiri knigi, 252.

${ }^{107}$ Tikhon, Tvoreniia II, 337.

${ }^{108}$ Arndt, Chtiri knigi, 158.

${ }^{109}$ Tikhon, Tvoreniia II, 340.

${ }^{110}$ Arndt, Chtiri knigi, 259.

${ }^{111}$ Ibid.

${ }^{112}$ Tikhon, Tvoreniia II, 338.

${ }^{113}$ Ibid., 337.

${ }^{114}$ Ibid., 342; Arndt, Chtiri knigi, 183-184.

${ }^{115}$ Arndt, Chtiri knigi, 259. Fortior est qui se, quam qui fortissima vincit moenia.

${ }^{116}$ Ibid.

${ }^{117}$ Tikhon, Tvoreniia II, 338

${ }^{118}$ Arndt, Chtiri knigi, 1384.

${ }^{119}$ Ibid. 1383.

${ }^{120}$ Tikhon, Tvoreniia III, 390. For a better assessment, compare Tikhon's "Радость без любви не бывает, и где любовь тамо и радость. А кто любит что, о том радуется” (Ibid., 39o) against Arndt's “Идеже бо несть любви тамо и радость не может быти, понеже радость от любви раждается. Каковая же любовь таковая и радость” (Chtiri knigi, 1385).

${ }_{121}^{121}$ Tikhon, Tvoreniia II, 261.

${ }^{122}$ Tikhon, Tvoreniia III, 390.

${ }^{123}$ Arndt, Chtiri knigi, 512.

${ }^{124}$ Arndt, Chtiri knigi, 1386.

${ }^{125}$ Arndt, Chtiri knigi, 1384.

${ }^{126}$ Tikhon, Tvoreniia III, 391.

${ }^{127}$ Ibid., 392.

${ }^{128}$ Arndt, Chtiri knigi, 1384.

${ }^{129}$ Ibid., 1385.

${ }^{130}$ Tikhon, Tvoreniia III, 392.

${ }^{131}$ Tikhon, Tvoreniia II, 238.

${ }^{132}$ Arndt, Chtiri knigi,619-620.

${ }^{133}$ Tikhon, Tvoreniia II, 270; Arndt, Chtiri knigi, Book II, Chapter 35.

${ }^{134}$ Tikhon, Tvoreniia II, 266; Arndt, Chtiri knigi, 839-840.

${ }^{135}$ Zdenek V. David, "The Influence of Jacob Boehme on Russian Religious Thought, Slavic Review 21:1 (Mar., 1962): 46-51. Filaret, Obzor russkoi dukhovnoi literatury 862-1863 vol. I (St. Petersburg: Izdaniie knigoprodavtsa I.L. Tuzova, 1884):360-369.

${ }^{136}$ Gorodetzky, Tikhon, 3.

${ }^{137}$ Among his works are Holy Observations (London: Printed by Tho: Purfoot for Samuell Macham, 1609); Meditations and Vows, divine and morall (London: Printed by W. Stansby for H. Fetherstone, 1621), The Breathings of the Devout Soul (London, s.i., 1648), Soliloquies or Holy Selfe-Conferences of the Devout Soul (London: W.H., 1659) and more. 
${ }^{138}$ This style of writing developed in England as a Protestant response to the popularity of the devotional exercises of Ignatius of Loyola, and trace their roots to the similar devotional literature of the High Middle Ages, such as Thomas à Kempis' Imitatio Christi. Frank L Huntley, Bishop Joseph Hall and Protestant Meditationin Seventeenth-Century England: A Study. (Binghamton, NY: Center for Medieval and Early Renaissance Studies, 1981) 3-5, for the discussion of influence on Puritan meditations, see pages 52-58. For the relevant research on Joseph Hall in the continental European devotional context see, Udo Strater, Sonthom, Bayly, Dyke und Hall: Studien zur Rezeption der englischen Erbauungsliteratur in Deutschland im 17. Jahrhundert (Tübingen: Mohr, 1987).

${ }^{139}$ Gorodetzky, Tikhon, 51, 98; Florovsky, Puti, 123. For the discussion of the 1630 and 1633 English editions of Hall, see Huntley, Bishop Joseph Hall, 6o-61.

${ }^{140}$ Josephi Halli Exoniensis Episcopi. vel, Meditatiunculae subitaneae (London: Impensis Nath. Butter, 1635), Josephi Halli Exoniensis Episcopi...Meditatiunculae subitaneae (Königsberg: Hallervordius 1672)

${ }^{141}$ The influence of Arndt in the Spiritual Treasure is seen in comparing this work with Arndt's discussion of the "great and inward Treasure," in Arndt, Chtiri knigi, 1003-1005.

${ }^{142}$ Tikhon, Tvoreniia II, pages 15-108.

143 "Primechaniia," in Tikgon of Zadonsk, Tvoreniia III (1889 edition), p.ii

${ }^{144}$ Unlike the chapters in the Spiritual Treasure, the insert's meditations are as short as those in Hall's: at most one or two paragraphs, with no extended theological commentaries. The insert is also an earlier work, originating from the time of Tikhon's lectures at Tver' seminary, which in itself may suggest that the saint initially used a more direct appropriation of Hall in his pedagogical practice, and then refined the use of the genre later in writing a more original work.

${ }^{145}$ Tikhon, Tvoreniia II pp. 19-26, 27, 33.

${ }^{146}$ Ibid., 28.

${ }^{147}$ Ibid., 53, 61, 15 .

${ }^{148}$ Meditation numbers XXIX, XI, XXVII LII XXXVIII, LXIV, LXXIII, CXXXIV, for videre, see XLV, LIII in both the English edition and the Latin edition. The English edition of 1633 cited here is a reprint, published in "Occasional Meditations (1633)," in Frank L. Huntley, Bishop Joseph Hall and Protestant Meditation, 119-211. The Latin edition cited here is Joseph Hall, Josephi Halli Exoniensis Episcopi. vel, Meditatiunculae subitaneae (London: Impensis Nath. Butter, 1635).

${ }^{149}$ Ibid., Meditation numbers XLVII.

${ }^{150}$ Ibid., Meditation numbers LXV, LXXI, LXXXIV.

${ }^{151}$ Ibid., Meditation numbers, CI, CIV, CXXXII.

152 "Proloquium ad Lectorem," in Josephi Halli Exoniensis Episcopi. vel, Meditatiunculae subitaneae, pp. A6-A9.

${ }^{153}$ Tikhon, Tvoreniia II, 108.

${ }^{154}$ Ibid.

${ }^{155}$ Hall, "Occasional Meditations (1633)" and Josephii Halli, meditation I.

${ }^{156}$ Tikhon, "Sluchai," 15. Unlike Tikhon in this meditation, Joseph Hall overly emphasizes the perpetual motion (not the fixed position) of the earth itself, not just the sky, arguing that the moral of this story lies in the necessity of the believer to be in perpetual spiritual motion too. Tikhon, however, does not emphasize the motion of the planet Earth, just the sky and the clouds above him. It is plausible (but not certain) that Tikhon may have had his own reservations about the Copernican universe while reading Hall.

${ }^{157}$ Hall, "Occasional Meditations (1633)" and Josephii Halli, meditation XXII, In the English version, Hall writes his title as the "blowing of the fire." Tikhon, Tvoreniia II, 18;

${ }^{158}$ Tikhon, Tvoreniia II, 18; Joseph Hall, "Occasional Meditations (1633)," 135.

${ }^{159}$ Ibid.

${ }^{160}$ Tikhon, Tvoreniia II, 94, Hall, “Occasional Meditations (1633),” meditation IX. 
${ }^{161}$ Hall, "Occasional Meditations (1633)," and Josephii Halli, meditation XX. Meditation XX is continued in the meditation XXI, as an observation "on the same occasion."

${ }^{162}$ Ibid.

${ }^{163}$ Tikhon, Tvoreniia II, 34.

${ }^{164}$ Hall, "Occasional Meditations (1633)" and Josephii Halli, meditation LVII.

${ }^{165}$ Tikhon, 24.

${ }^{166}$ Tikhon, Tvoreniia II, 55; Hall, “Occasional Meditations (1633)," LXXIIII.

${ }^{167}$ Hall, XLIIII.

${ }^{168}$ Hall, LXXXII.

${ }^{169}$ Tikhon, Tvoreniia II, 21.

${ }^{170}$ Ibid.

${ }^{171}$ A. S. Lavrov, Koldovstvo i religiia v Rossii: 1700-1740 gg. (Moscow: Drevlekhranilishche, 200o); Also, "Le ritual ecclesiastique et la religion populaire en Russie au 17e siècle," in Jose Pedro Paiva, ed., Religious Ceremonials and Images: Power and Social Meaning 1400-1750 (Coimbra: Palimage Editores, 2002): 369-387 and "Petrovskaia reforma i russkaia religioznost" in Poiski istoricheskoi psikhologii vol. 3 (St. Petersburg: Tret'ia Rossiia, 1997): 15-18; Gregory Freeze, "The Rechristianization of Russia: The Church and Popular Religion, 1750-1850," Studia Slavica Finlandensia 7 (1990) and The Russian Levites (Cambridge, MA: Harvard University Press, 1977); Robert O. Crummey, "Ecclesiastical Elites and Popular Belief and Practice in Seventeenth Century Russia" in James Tracy and Marguerite Ragnow, eds., Religion and the Early Modern State (Cambridge: Cambridge University Press, 2004): 52-80. 